\title{
Diethyllead as a specific indicator of occupational exposure to tetraethyllead
}

\author{
Z TURLAKIEWICZ' AND J CHMIELNICKA ${ }^{2}$
}

From the Instituie of Occupational Medicine, ${ }^{1}$ Department of Toxic Compounds Metabolism, Lodz, and Medical Academy of Lodz, ${ }^{2}$ Institute of Environmental Research and Bioanalysis, Department of Toxicological Chemistry, Lódź, Poland

ABSTRACT In a group of 26 workers exposed to tetraethyllead a correlation was found between the concentration of tetraethyllead in the air and the concentration of diethyllead $(r=0 \cdot 70)$ and total lead $(r=0.84)$ in the urine and also between the excretion of diethyllead and total lead $(r=$ $0.68)$. The results obtained indicate that diethyllead may be used as a specific indicator of occupational exposure to tetraethyllead.

The evaluation of occupational exposure to neurotoxic compounds such as tetraethyllead $\left(\mathrm{Et}_{4} \mathrm{~Pb}\right)$, which is still used in some countries as an antiknock agent in petrol, demands an urgent solution. Biochemical tests used in evaluating exposure to inorganic lead compounds are not specific for these compounds. ${ }^{1-6}$

Tetraethyllead is metabolised to triethyllead $\left(\mathrm{Et}_{3} \mathrm{~Pb}^{+}\right)$, diethyllead $\left(\mathrm{Et}_{2} \mathrm{~Pb}^{+2}\right)$, and ionic lead $\left(\mathrm{Pb}^{+2}\right){ }^{\text {? }}$ -10 Some data have shown that in the case of acute $\mathrm{Et}_{\mathbf{4}} \mathrm{Pb}$ poisoning in man the predominant metabolite excreted in the urine is $\mathrm{Et}_{2} \mathrm{~Pb}^{+2.9}{ }^{10}$ The main problem in establishing the use of this metabolite in evaluating occupational exposure has seen the lack of specific analytical methods. It has been suggested by Chiesura that $\mathrm{Et}_{2} \mathrm{~Pb}^{+2}$ could be used as a specific indicator of occupational exposure to $\mathrm{Et}_{4} \mathrm{~Pb}^{7}$ and our initial research using the modified method of Yamamuchi ${ }^{10}$ also indicates this.

The aim of the present work was to study a group of people occupationally exposed to $\mathrm{Et}_{4} \mathrm{~Pb}$ to establish whether the excretion of $\mathrm{Et}_{2} \mathrm{~Pb}^{+2}$ in the urine may be used as a specific indicator of occupational exposure.

\section{Materials and methods}

A group of 26 men employed by a petrol company and a control group of men not exposed to $\mathrm{Et}_{4} \mathrm{~Pb}$ were studied.

$\mathrm{Et}_{4} \mathrm{~Pb}$ in the atmosphere was evaluated by a modified spectrophotometric dithizone method. The

Received 5 November 1984

Accepted 7 January 1985 principle of this method depends on the absorption of $\mathrm{Et}_{4} \mathrm{~Pb}$ on to carbon and the deabsorption and mineralisation of the sample followed by spectrophotometric determination of the dithizonate complex. The limits of detection through this method are $2.5 \mu \mathrm{gEt}_{4} \mathrm{~Pb} / \mathrm{m}^{3}$ air (M Dobecki, unpublished data).

Test samples of air were obtained from an are where the workers were respiring using person samplers. The total lead blood concentration ( $\mathrm{Pb}-\mathrm{B})$ in the exposed and control group was evaluated by flameless AAS.*

After evaluating the concentration of creatinine and the specific gravity of the urine, the level of total lead $(\mathrm{Pb}-\mathrm{U})$ was determined using a flameless AAS method, whereas $\mathrm{Et}_{2} \mathrm{~Pb}^{+2}$ was evaluated using our modified flameless AAS method. ${ }^{10}$ The results of $\mathrm{Pb}-\mathrm{U}$ and $\mathrm{Et}_{2} \mathrm{~Pb}^{+2}$ were adjusted to the average specific gravity of urine (1.024).

\section{Results}

Table 1 and fig 1 present the data on the degree of $\frac{}{2}$ occupational exposure to $\mathrm{Et}_{4} \mathrm{~Pb}$, depending on the $\frac{}{2}$ workplace. The results obtained indicate that the magnitude of exposure to $\mathrm{Et}_{4} \mathrm{~Pb}$ in the population $\mathrm{N}$ studied, as defined by the modal value, varied greatly. The workers exposed to the highest $O$ concentration of $\mathrm{Et}_{4} \mathrm{~Pb}$ were those adding $\mathrm{Et}_{4} \mathrm{~Pb}$ to $\mathrm{\omega}$ petrol (workplace No 3). Workers servicing rail tankers (petrol) were less exposed (workplace No 2) 을

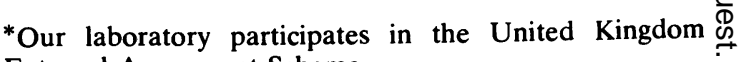

External Assessment Scheme. 
Table 1 Concentrations of $E t_{4} P b$ in the air $\left(m g / m^{3}\right)$ by workplace $(8 h-T W A)$

\begin{tabular}{lccccc}
\hline No of workplace and occupation & No of workers & Mean & Median & Mode & Range \\
\hline 1 Loading petrol into tankers & 7 & $0 \cdot 015$ & 0.007 & $0 \cdot 009$ & $0.004-0.050$ \\
2 Loading petrol into rail tankers & 14 & 0.012 & 0.009 & $0 \cdot 016$ & $0.004-0.026$ \\
3 Adding Et ${ }_{4} \mathrm{~Pb}$ to petrol & 5 & $0 \cdot 205$ & $0 \cdot 140$ & $0 \cdot 480$ & $0.050-0.810$ \\
\hline
\end{tabular}

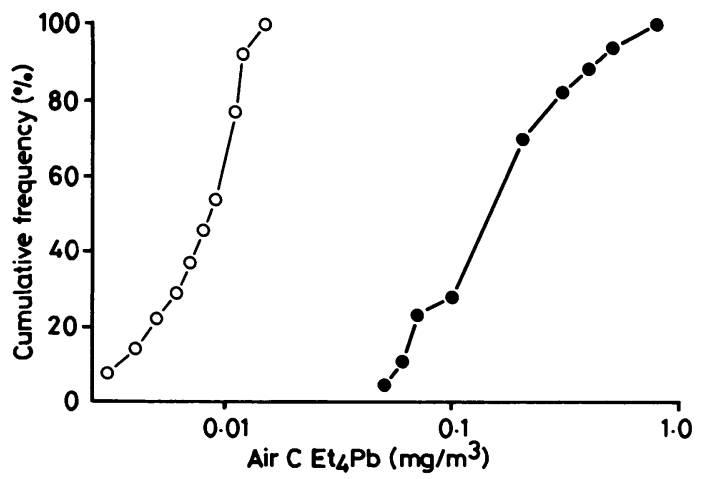

Fig 1 Cumulative frequency: percentage of workers exposed to $\mathrm{Et}_{4} \mathrm{~Pb}$. $\bigcirc-\bigcirc$ Workplaces Nos 1 and 2, workplace No 3.

and those with the least exposure were loading petrol into tankers (workplace No 1).

Table 2 includes a description of the men occupationally exposed to $\mathrm{Et}_{4} \mathrm{~Pb}$, and their concentrations of total lead $(\mathrm{Pb}-\mathrm{U})$ and $\mathrm{Et}_{2} \mathrm{~Pb}^{+2}$ in urine and also the concentration of total lead in the blood $(\mathrm{Pb}-\mathrm{B})$. Similar data for the control group are in table 3.

The cumulative frequency graph shows the excretion of $\mathrm{Pb}-\mathrm{U}$ (fig $2 \mathrm{a}$ ) and $\mathrm{Et}_{2} \mathrm{~Pb}^{+2}$ (fig $2 \mathrm{~b}$ ) in the urine of the test workers, according to their workplace. In the workers exposed to the lowest concentrations of $\mathrm{Et}_{4} \mathrm{~Pb}$ (workplace Nos 1 and 2) the excretion of $\mathrm{Pb}-\mathrm{U}$ was not greater than $60 \mu \mathrm{gPb} / \mathrm{l}$. In $50 \%$ of these workers no urinary excretion of $\mathrm{Et}_{2} \mathrm{~Pb}^{+2}$ was found. In the remainder the amount excreted in the urine did not exceed $8 \mu \mathrm{g} \mathrm{Et}_{2} \mathrm{~Pb}^{+2} / \mathrm{l}$. In the workers exposed to the highest concentration of $\mathrm{Et}_{4} \mathrm{~Pb}$ (workplace No 3) the amount of metabolite excreted in the urine was significantly higher than in the less exposed workers. The concentration of $\mathrm{Pb}-\mathrm{U}$ in the urine ranged from 35 to $230 \mu \mathrm{g} \mathrm{Pb} / \mathrm{l}$ and the concentration of $\mathrm{Et}_{2} \mathrm{~Pb}^{+2}$ in the urine ranged from 2.5 to $27 \mu \mathrm{g} / \mathrm{l}$; in $50 \%$ of the workers at workplace No 3 the excretion of this metabolite was in excess of $7 \mu \mathrm{g} \mathrm{Et}_{2} \mathrm{~Pb}^{+2} / \mathrm{l}$.

Figure 3 shows a regression graph for the correlation between the concentration of $\mathrm{Et}_{4} \mathrm{~Pb}$ in the air and the excretion of its metabolites in the urine $\left(\mathrm{Pb}-\mathrm{U}\right.$ fig $3 \mathrm{a}, \mathrm{Et}_{2} \mathrm{~Pb}^{+2}$ fig $\left.3 \mathrm{~b}\right)$. The data for

Table 2 Characteristics of the 26 workers exposed to $\mathrm{Et}_{4} \mathrm{~Pb}$

\begin{tabular}{|c|c|c|c|c|}
\hline Parameters & Mean & Median & Mode & Range \\
\hline $\begin{array}{l}\text { Age (years) } \\
\text { Years of employment } \\
\mathrm{Pb}-\mathrm{B}(\mu \mathrm{g} / \mathrm{l}) \\
\mathrm{Pb}-\mathrm{U}(\mu \mathrm{g} / \mathrm{l}) \\
\mathrm{Pb}-\mathrm{U}(\mu \mathrm{g} / \text { mean spec grav) } \\
\mathrm{Pb}-\mathrm{U}(\mu \mathrm{g} / \mathrm{g} \text { creatinine) } \\
\mathrm{Et}_{2} \mathrm{~Pb}_{2}^{+2}(\mu \mathrm{g} / \mathrm{l}) \\
\mathrm{Et}_{2} \mathrm{~Pb}^{+2} \text { (mean spec grav) } \\
\mathrm{Et}_{2} \mathrm{~Pb}^{+2} \text { ( } \mu \mathrm{g} / \mathrm{g} \text { creatinine) } \\
\text { Specific gravity of urine } \\
\text { Creatinine (mg/ml) }\end{array}$ & $\begin{array}{c}35 \cdot 6 \\
8 \cdot 1 \\
256 \cdot 3 \\
73 \cdot 8 \\
84 \cdot 6 \\
42 \cdot 2 \\
6 \cdot 6 \\
8 \cdot 6 \\
4 \cdot 4 \\
1 \cdot 021 \\
2 \cdot 00\end{array}$ & $\begin{array}{c}30 \cdot 0 \\
7 \cdot 5 \\
240 \cdot 0 \\
72 \cdot 8 \\
83 \cdot 3 \\
36 \cdot 2 \\
5 \cdot 5 \\
6 \cdot 3 \\
3 \cdot 4 \\
1 \cdot 022 \\
1 \cdot 87\end{array}$ & $\begin{array}{c}30 \cdot 0 \\
10 \cdot 0 \\
325 \cdot 0 \\
78 \cdot 4 \\
117 \cdot 6 \\
56 \cdot 0 \\
4 \cdot 0 \\
8 \cdot 0 \\
4 \cdot 0 \\
1 \cdot 025 \\
1 \cdot 50\end{array}$ & $\begin{array}{c}26 \cdot 0-58 \cdot 0 \\
0 \cdot 5-22 \cdot 0 \\
190 \cdot 0-535 \cdot 0 \\
16 \cdot 8-229 \cdot 6 \\
22 \cdot 1-165 \cdot 6 \\
9 \cdot 0-128 \cdot 0 \\
3 \cdot 0-25 \cdot 0 \\
2 \cdot 7-27 \cdot 2 \\
1 \cdot 1-24 \cdot 3 \\
1 \cdot 005-1 \cdot 030 \\
0 \cdot 55-4 \cdot 50\end{array}$ \\
\hline
\end{tabular}

Table 3 Characteristics of the control group $(n=26)$

\begin{tabular}{|c|c|c|c|c|}
\hline Parameters & Mean & Median & Mode & Range \\
\hline $\begin{array}{l}\text { Age (years) } \\
\mathrm{Pb}-\mathrm{B}(\mu \mathrm{g} / \mathrm{l}) \\
\mathrm{Pb}-\mathrm{U}(\mu \mathrm{g} / \mathrm{l}) \\
\mathrm{Pb}-\mathrm{U}(\mu \mathrm{g} / \text { mean spec grav }) \\
\mathrm{Pb}-\mathrm{U}(\mu \mathrm{g} / \mathrm{g} \text { creatinine) } \\
\mathrm{Et}_{2} \mathrm{~Pb}{ }_{2}\left(\mu \mathrm{g} / \mathrm{l}^{*}\right) \\
\text { Specific gravity of urine } \\
\text { Creatinine }(\mathrm{mg} / \mathrm{ml})\end{array}$ & $\begin{array}{c}34 \cdot 2 \\
105 \cdot 7 \\
24 \cdot 9 \\
31 \cdot 8 \\
19.3 \\
-\quad 1.020 \\
1.63\end{array}$ & $\begin{array}{l}34 \cdot 0 \\
90 \cdot 0 \\
25 \cdot 0 \\
28 \cdot 4 \\
15 \cdot 4 \\
-1 \cdot 020 \\
1 \cdot 40\end{array}$ & $\begin{array}{r}30 \cdot 0 \\
100 \cdot 0 \\
27 \cdot 5 \\
30 \cdot 0 \\
25 \cdot 0 \\
-\quad 1 \cdot 624 \\
1 \cdot 20\end{array}$ & $\begin{array}{l}24 \cdot 0-47 \cdot 0 \\
55 \cdot 0-160 \cdot 0 \\
7 \cdot 5-55 \cdot 0 \\
9 \cdot 3-72 \cdot 0 \\
6 \cdot 7-44 \cdot 5 \\
-\quad \\
1 \cdot 005-1 \cdot 030 \\
0 \cdot 9-5 \cdot 5\end{array}$ \\
\hline
\end{tabular}

${ }^{*} \mathrm{Et}_{2} \mathrm{~Pb}^{+2}-$ undetected. 


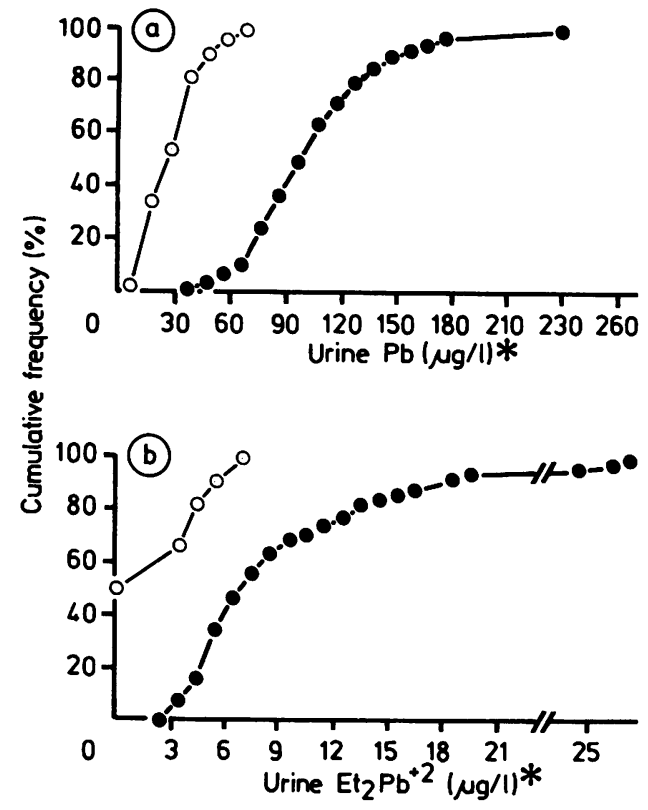

Fig 2 Cumulative frequency: urinary excretion of (a) $P b-U$ and (b) $E t_{2} P b^{+2}$. $\bigcirc-O$ Workplaces Nos 1 and 2, - workplace No 3. (Results adjusted to average specific gravity of urine.)
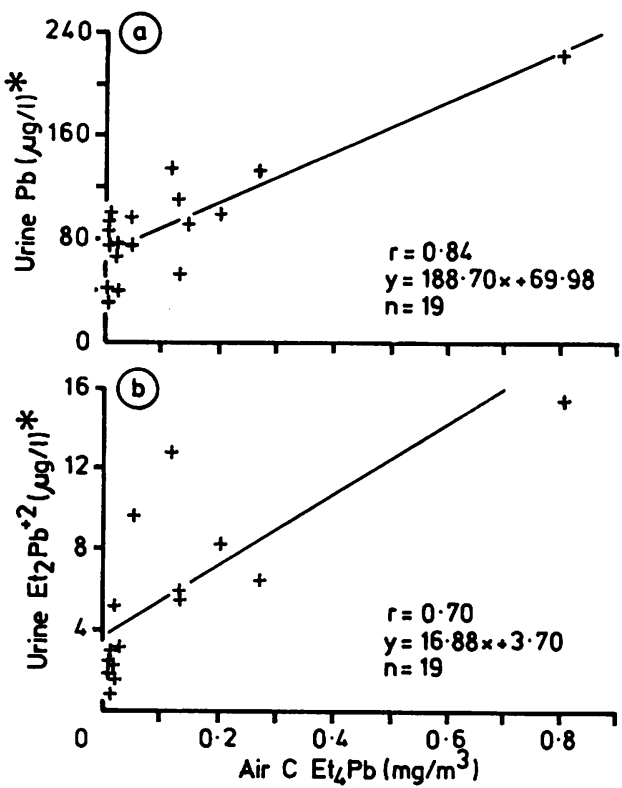

Fig 3 Correlation between concentrations of $\mathrm{Et}_{4} \mathrm{~Pb}$ in air and (a) concentration of $P b-U$ and (b) concentration of $\mathrm{Et}_{2} \mathrm{~Pb}^{+2}$ in urine. (Results adjusted to average specific gravity of urine -1.024 .)
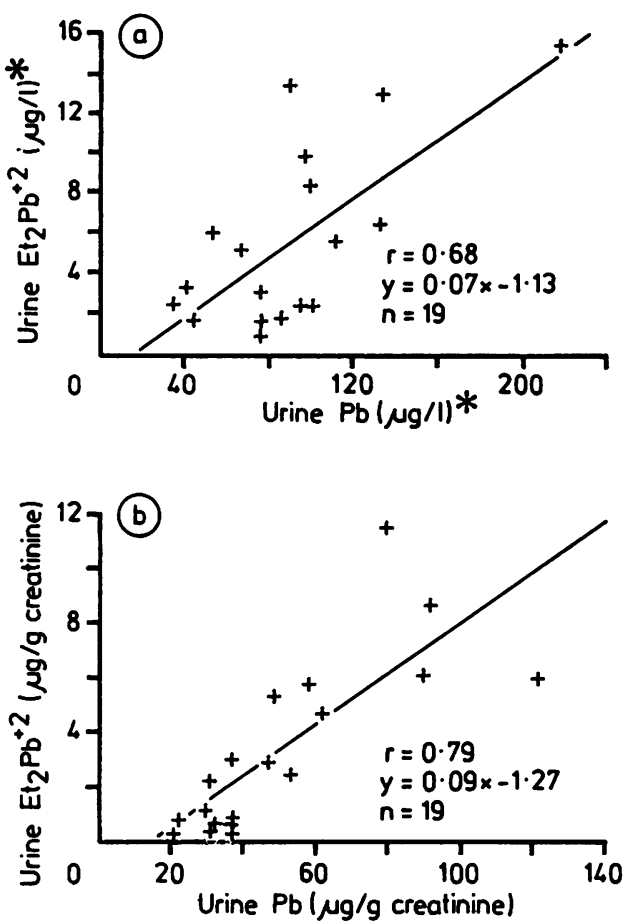

Fig 4 Correlation between concentrations of $\mathrm{Et}_{2} \mathrm{~Pb}^{+2}$ an $\$$ total lead in urine. ((a) Results adjusted to average specific gravity of urine - 1.024; (b) Results calculated per gram creatinine.)

those workers in whom the $\mathrm{Pb}-\mathrm{U}$ concentration was less or equal to that of the control group have not been included. The results obtained show a positive correlation between the concentration of $\mathrm{Et}_{4} \mathrm{~Pb}$ in air and the amount of $\mathrm{Pb}-\mathrm{U}$ and $\mathrm{Et}_{2} \mathrm{~Pb}^{+2}$ in the urine ( $r=0.84$ and $r=0.70$ respectively). A positive correlation (fig 4) was also found between the excretion of $\mathrm{Pb}-\mathrm{U}$ and $\mathrm{Et}_{2} \mathrm{~Pb}^{+2}$ in the urine.

A small positive correlation was found between the concentration of $\mathrm{Et}_{4} \mathrm{~Pb}$ in the air and $\mathrm{Pb}-\mathrm{B}(\mathrm{r}=$ $0 \cdot 11)$ but no correlation was found between $\mathrm{Pb}-\mathrm{B}$ and the concentrations of $\mathrm{Pb}-\mathrm{U}$ and $\mathrm{Et}_{2} \mathrm{~Pb}^{+2}$ in the urine.

\section{Discussion}

The concentrations of $\mathrm{Pb}-\mathrm{B}$ in people with clinical 0 symptoms of $\mathrm{Et}_{4} \mathrm{~Pb}$ poisoning have been found to be $\tilde{O}$ higher than $500 \mu \mathrm{g} / \mathrm{l}^{4-6}$ Observations made by $\underset{\mathrm{\omega}}{N}$ Robinson showed that the concentration of $\mathrm{Pb}-\mathrm{B}$ in people who had been exposed to $\mathrm{Et}_{4} \mathrm{~Pb}$ for 20 years ranged from 200 to $500 \mu \mathrm{g} / 1^{\prime \prime}$ but that none suffered $\frac{2}{\Phi}$ any detectable impairment in health. Millar et al $\stackrel{\oplus}{?}$ showed that in people occupationally exposed to 
$\mathrm{Et}_{4} \mathrm{~Pb}$ the mean concentration of $\mathrm{Pb}-\mathrm{B}$ rose to $425 \mu \mathrm{g} / \mathrm{l}$ and the activity of ALA-dehydratase (ALA-D) was significantly reduced. ${ }^{3}$ Studies made by Piotrowski and O'Brien, however, have shown that the activity of ALA-D is a subcritical indicator for the evaluation of lead poisoning. ${ }^{12}$

These results and those of our studies indicate that the evaluation of $\mathrm{Pb}-\mathrm{B}$ is of little use in estimating the extent of occupational exposure to $\mathrm{Et}_{4} \mathrm{~Pb}$.

The concentration of $\mathrm{Pb}-\mathrm{U}$ in $80 \%$ of workers exposed to $\mathrm{Et}_{4} \mathrm{~Pb}$ for 20 years ranged from 30 to $120 \mu \mathrm{g} / \mathrm{l} .{ }^{.1}$ In our studies on workers exposed for 10 years the level of $\mathrm{Pb}-\mathrm{U}$ ranged from 16 to $229 \mu \mathrm{g} / \mathrm{l}$. The mean concentration of $\mathrm{Pb}-\mathrm{U}(73.8 \mu \mathrm{g} / \mathrm{l})$ was lower than those $\left(150 \mu \mathrm{g} \mathrm{Pb} / 1^{13}\right.$ and $\left.110 \mu \mathrm{g} \mathrm{Pb} / 1^{14}\right)$ which have been recognised as being without hazard for workers occupationally exposed to $\mathrm{Et}_{4} \mathrm{~Pb}$. As shown by fig $2 a$, despite high concentrations of $\mathrm{Et}_{4} \mathrm{~Pb}$ in the air only three workers of the test group exhibited $\mathrm{Pb}-\mathrm{U}$ excretion higher than the one quoted above.

With respect to the above, it seems that the concentration of $\mathrm{Pb}-\mathrm{U}$ is also of little use as an indicator of occupational exposure to $\mathrm{Et}_{4} \mathrm{~Pb}$.

On the other hand, $\mathrm{Et}_{2} \mathrm{~Pb}^{+2}$ was found in the urine of workers exposed to both high and low concentrations of $\mathrm{Et}_{4} \mathrm{~Pb}$. A significant correlation was found between the concentration of $\mathrm{Et}_{4} \mathrm{~Pb}$ in the air and excretion of $\mathrm{Et}_{2} \mathrm{~Pb}^{+2}$ in the urine $(\mathrm{r}=0.70)$. These show that this metabolite could be a specific indicator for occupational exposure to $\mathrm{Et}_{4} \mathrm{~Pb}$.

The concentrations ratios between $\mathrm{Et}_{2} \mathrm{~Pb}^{+2} /$ total $\mathrm{Pb}$ in the urine of exposed workers differed. For workers employed at workplaces Nos 1 and 3 (table 1) the mean ratios were 0.093 (from 0.04 to 0.19 ) and 0.085 (from 0.049 to 0.14 ), respectively. On the other hand, in cases of acute poisoning the mean ratio was 0.35 (from 0.08 to 0.72 ). ${ }^{y}{ }^{10}$

These results would make us surmise that the metabolism of $\mathrm{Et}_{4} \mathrm{~Pb}$ to $\mathrm{Et}_{2} \mathrm{~Pb}^{+2}$ depends on the dose or the extent of exposure.

In people occupationally exposed to $\mathrm{Et}_{4} \mathrm{~Pb}$ the urinary level of $\mathrm{Pb}-\mathrm{U}$ of $110 \mu \mathrm{g} / \mathrm{g}$ creatinine has been assumed as safe..$^{15}$ Figure $4 \mathrm{~b}$ shows the correlation between the excretion of $\mathrm{Pb}-\mathrm{U}$ and $\mathrm{Et}_{2} \mathrm{~Pb}^{+2}$ in the urine (per gram creatinine): these data indicate that the permissible level of $\mathrm{Et}_{2} \mathrm{~Pb}^{+2}$ in the urine of workers occupationally exposed is about $8 \mu \mathrm{g}$. Hence it would seem that the detection of this metabolite at a concentration greater than $8 \mu \mathrm{g}$ could indicate that the exposure may be hazardous to health.

This study was supported by the programme of the Polish Ministry of Health and Social Welfare, grant MZ-IX.1.16.

\section{References}

' Crept M, Chiesura P. Porphyrins in tetraethyl lead poisoning. Panminerva Medica 1966; 7-8:295-301.

${ }^{2}$ Foa V, Cavagna G, Manfredi M. Evaluation of urinary lead in the diagnosis of tetraethyl lead poisoning. Med Lav 1970; 10:491-501.

${ }^{3}$ Millar JA, Thomson GG, Goldberg A, Barry PSI, Lowe EH. S-Aminolevulinic acid dehydrase activity in the blood of men working with lead alkyls. Br J Ind Med 1972;29:317-20.

${ }^{4}$ Beattie AD, Morre MR. Tetraethyl-lead poisoning. Lancet 1971;i:12-5.

${ }^{5}$ Robinson TR, Rouge B. Delta-aminolevulinic acid and lead in urine of lead antiknock workers. Arch Environ Health 1974;28: 133-6.

- Yamamura Y, Takakura J, Hirayama F, Yamauchi H, Yohida M. Tetraethyl lead poisoning caused by cleaning work in the aviation fuel tank. Jap J Ind Health 1975;17:223-35.

${ }^{7}$ Chiesura P. Urinary excretion of lead tetraethyl catabolites in man. Med Lav 1970;61:437-41.

${ }^{8}$ Bolanowska W, Piotrowski J, Garczyński H. Triethyllead in the biological material in cases of acute tetraethyllead poisoning. Archiv für Toxikologie 1967;22:276-82.

4 Yamamura Y, Arai F, Yamauchi H. Urinary excretion pattern of triethyllead, diethyllead and inorganic lead in the tetraethyllead poisoning. Ind Health 1981;19:125-31.

10 Turlakiewicz Z, Jakubowski M, Chmielnicka J. Determination of diethyllead in urine by flameless atomic absorption spectrometry. Br J Ind Med 1985;42:63-5.

"Robinson TR. The health of long service tetraethyllead lead workers. J Occup Med 1976; 18:31-49.

${ }^{12}$ Piotrowski JK, O'Brien BJ. Analysis of the effects of lead in tissue upon human health using dose-response relationship. Progress Reports in Environmental Monitoring and Assessment 1980; 1:72-88.

${ }^{13}$ Kehoe RA. Lead, alkyl compounds. Geneva: Occupational Health and Safety ILO, 1972:765.

${ }^{14}$ Chiesura P, Danielli A. Urinary lead and judgment of tetraethyl poisoning. Investigation among workers engaged in production. Med Lav 1969;60:129-37.

is Lauwerys R, Buchet JP, Roels H. Caharien de Medicine du Travail 1980; 17:91-7. 